\title{
Surficial Geology and Geologic Hazards of Bonita and Rhyolite Canyons, Chiricahua National Monument, Arizona
}

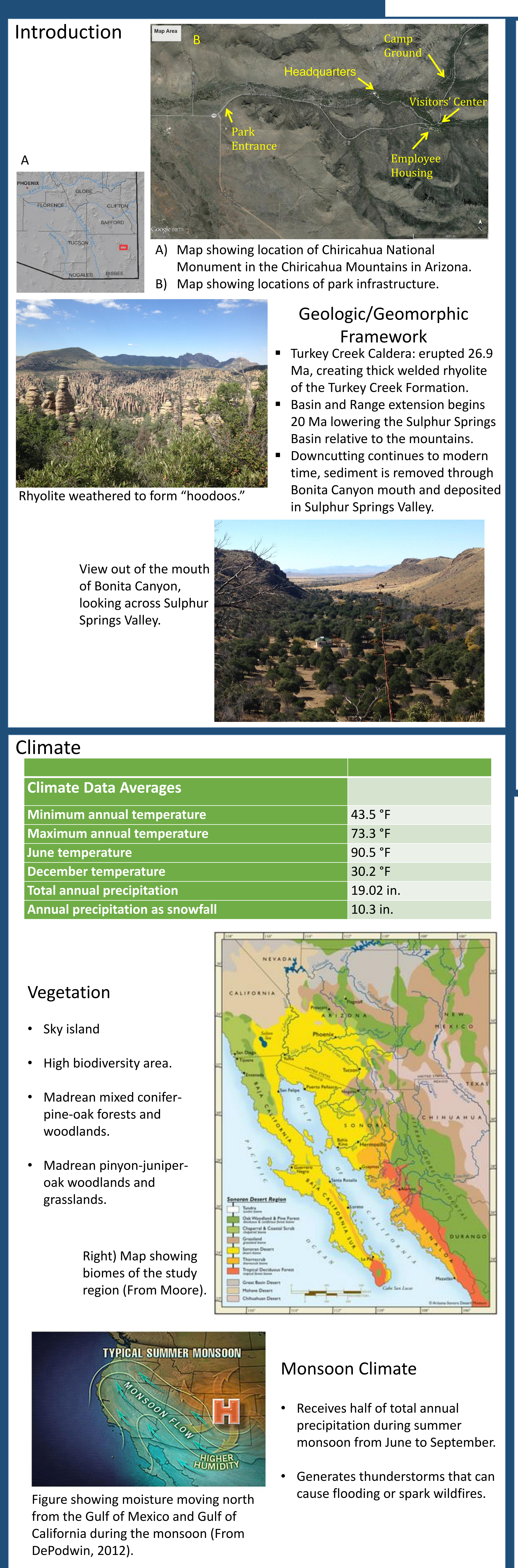

Kristin S. Pearthree ${ }^{1}$ and Ann Youberg ${ }^{2}$
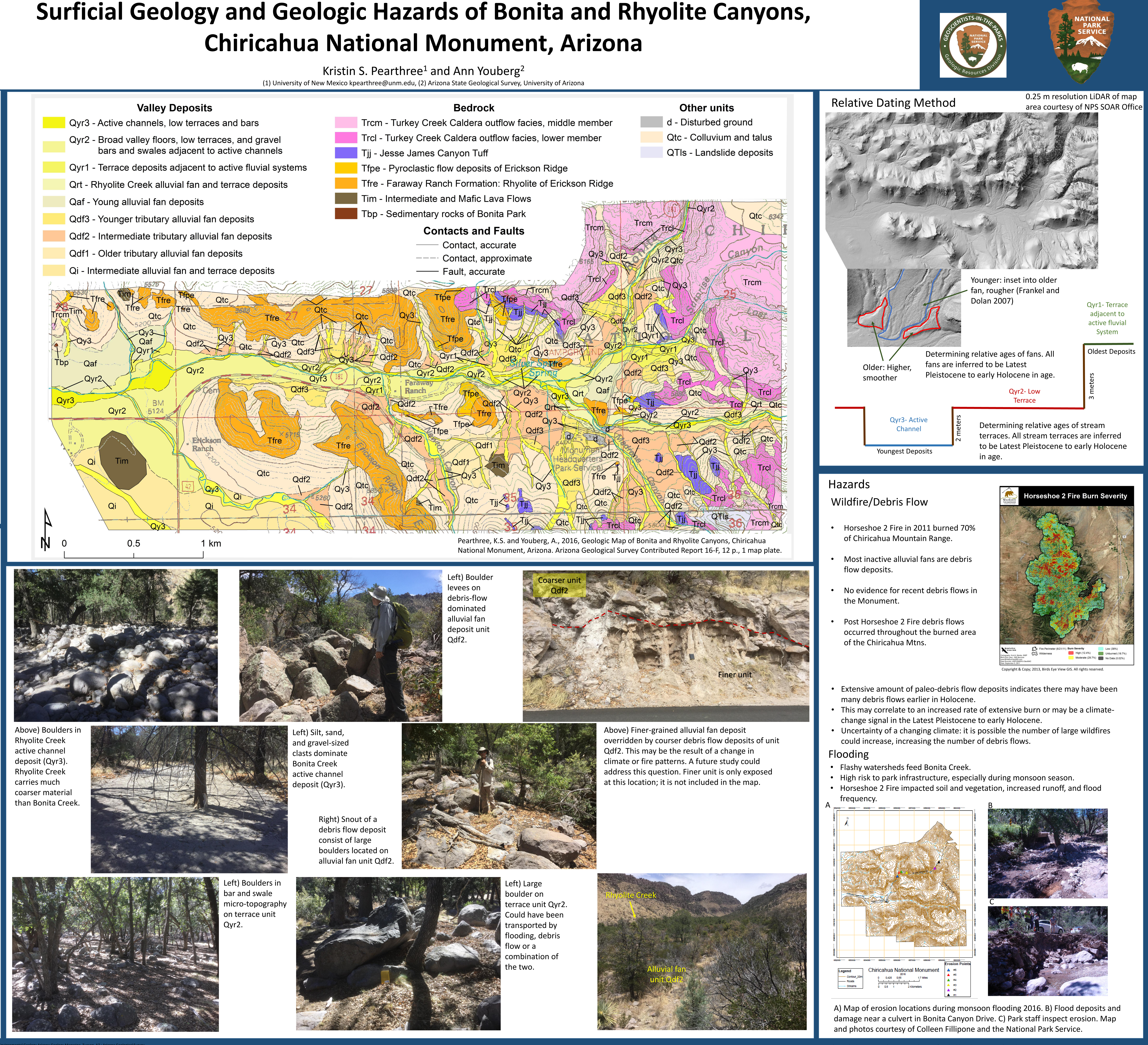